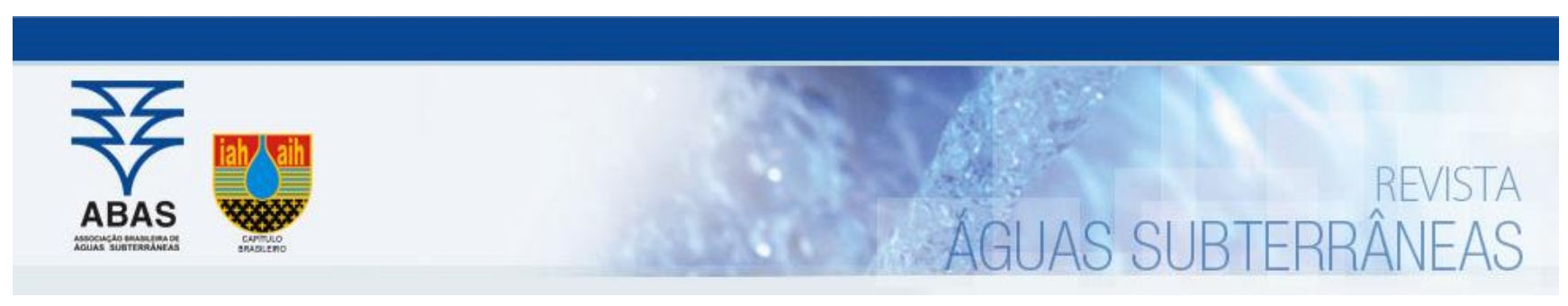

Papers

\title{
Correlations between physico-chemical properties and nickel adsorption parameters in soils used in sanitary landfill liners
}

\section{Correlações de propriedades físico-quimicas com parâmetros de adsorção de níquel em solos utilizados em liners de aterro sanitário}

\author{
Ricardo Antonio Ferreira da Silva1; Danilo Brito da Costa2; William de Paiva1; Márcio Camargo de Melo² ; Veruschka Escarião \\ Dessoles Monteiro ${ }^{\square}$
}

1 State University Of Paraíba (UEPB), Campina Grande, PB

2 Federal University of Campina Grande (UFCG), Campina Grande, PB

ricardoantonio0109@gmail.com, danilo.b.costa@hotmail.com,wpaiva461@gmail.com, melomc90@gmail.com, veruschkamonteiro@hotmail.com

\author{
Keywords: \\ Heavy metals. \\ Contamination. \\ Surface and groundwaters. \\ Batch equilibrium. \\ Adsorption isotherms.
}

\begin{abstract}
The adsorption of heavy metals by sanitary landfill liners represents a measure of protection of surface and groundwaters against contamination by metals, mitigating risks to public health. Hence, this research aimed to identify, from correlations, the influence of physico-chemical properties of soils applied in landfill liners using nickel adsorption parameters. Batch equilibrium tests with initial nickel concentrations of 45 to $1440 \mathrm{mg}$.L-1 were performed in clayey sand and bentonite clay soil, as well as in mixtures. Nickel adsorption parameters from Freundlich and Langmuir isotherm models were obtained, exhibiting a better adjustment in the Freundlich model based on $\mathrm{R}^{2}$ and RMSE criteria. Thus, the addition of bentonite clay improved the adsorption to nickel, and the cationic exchange capacity (CEC) was the property that considerably influenced the metal retention in the studied soils.

Resumo

A adsorção de metais pesados por liners de aterros sanitários representa mais uma medida de proteção às águas subterrâneas e superficiais contra a contaminação por metais, amenizando os riscos à saúde pública. 0 objetivo deste trabalho foi identificar, a partir de correlações, a influência de propriedades físico-químicas de solos utilizados em liners de aterros sanitários com parâmetros de adsorção do níquel. Os solos de estudo, areia argilosa e argila bentonítica, foram submetidos a ensaios de equilíbrio em lote individualmente e em misturas, com solução contaminante de níquel de 45 a 1440 mg.L-1. Os parâmetros de adsorção do níquel foram obtidos pelos modelos de isotermas de Langmuir e Freundlich, apresentando melhor ajuste pelos critérios de R² e REQM no de Freundlich. Constatou-se melhor adsorção ao níquel à medida em que a argila bentonítica foi adicionada às misturas, sendo a capacidade de troca catiônica (CTC) a propriedade que mais influenciou na retenção do metal.

\section{INTRODUCTION}

Sanitary landfill liners are waterproofing barriers that aim to prevent the offsite migration of liquid and gaseous byproducts generated by landfills, avoiding a possible contamination of the underground, surface and groundwaters. The most used liners in landfill bases are composed by compacted layers of clayey soils or by the combination of these layers with geosynthetics, regarding minimum waterproofing requirements (LOCASTRO and DE ANGELIS, 2016). The exclusive use of clayey soils in landfill liners represents a more advantageous and economic alternative for regions of low economic power with availability of quarries in the surroundings, considering strict geotechnical engineering criteria.

The liquid byproduct produced by landfills, known as leachate, has as main toxic component heavy metals. These metals can be transported in soil by physical processes of advection or dispersion, and can also be retained as a result of chemical processes, such as adsorption (FETTER et al, 2018). The understanding of the influence of physico-chemical properties of soils in the adsorption of heavy metals is essential for the choice of materials to be used as base liners in sanitary landfills, and also contributes to an effective protection of natural resources. 
Urban solid residues (USR) have a considerable variety of materials composed by heavy metals, which incorporate to the leachate during the degradation process in the internal part of landfills. Among these materials are metal alloys, which may have additional percentages of nickel (ALBERTI et al, 2015). These alloys can be degraded in isolated environments, allowing the dissolution of non-leached metals (MARTINELLI et al, 2014). Generally, nickel can be in concentrations that extrapolate the limits required by regulations for leaching testes with USR (SILVA et al., 2015). However, even in the case these limits are not exceeded, long term contamination occurs, which represents an environmental threat if the metal flow is not contained by landfill liners.

Nickel mobility in soils is higher than the mobility of other metals with higher molar mass and atomic radius, such as lead, copper, and zinc (ELBANA et al., 2018). Thus, nickel is more susceptible to reach surface and groundwaters and can be introduced in the food chain, endangering human health (HAQUE, 2017; ABDELWAHEB et al., 2019).

Studies have evidenced that the effects of excessive nickel concentrations in human beings include skin irritation, damage to nervous and respiratory systems, and genetic modifications; it has also toxic and carcinogenic potential, whether by inhalation or when dissolved in water (NICKEL INSTITUTE, 2018). In face of this, environmental legislations have showed concern regarding the level of nickel concentration in soils and in surface and groundwaters for human consumption (CONAMA, 2005, 2008, 2009).

One of the existing alternatives aiming to the retention of heavy metals by soil is the adsorption technique, which is viable as it is a low cost and environmentally adequate application (TRIPATHI et al., 2016). The use of soil in landfill liners as a barrier for the metal flow represents a form of application of this technique. For a better efficiency of adsorption in soils, factors such as clay content, organic matter, $\mathrm{pH}$, cation exchange capacity (CEC), presence of oxides, and soil mineralogy should be considered (ALLEONI et al., 2005).
Research involving adsorption of heavy metals have been performed to evaluate the efficiency of the adsorptive capacity of soils. Some researchers have determined that characteristics such as organic matter and iron oxides have good correlation with the adsorptive capacity of metals in soil (SILVEIRA et al., 2002), which depends on the variation of $\mathrm{pH}$ in the medium (ZHU et al., 2018). Regarding sanitary landfills, recent studies have been developed aiming to improve the behavior of liners and mitigate the negative environmental impacts, such as hydric contamination (MOHAMMED et al., 2016; BURAGOHAIN et al., 2018; BUDIHARDJO, 2018; SOBTI and SINGH 2019).

Heavy metals retention in soils can be quantified using adsorption isotherms, representing the affinity of the metal in soil in function of the solute equilibrium concentration (SELIM, 2014). Langmuir and Freundlich isotherm models are widely used to evaluate the adsorption of metals in soils (SPARKS, 2003), as they provide parameters that can be correlated to physico-chemical properties of the soil.

This work aims to identify, from correlations, the influence of physico-chemical properties of soils used in sanitary landfill liners in the nickel adsorption parameters estimated by Freundlich and Langmuir non-linear models.

\section{MATERIAL AND METHODS}

\subsection{Studied soils}

The soils used in this work compose the base liners in the Campina Grande Sanitary Landfill (CGSL), located in the countryside of Paraíba state (Brazil), at geographic coordinates $7^{\circ} 16^{\prime} 44^{\prime \prime}$ 'S and $36^{\circ} 00^{\prime} 44^{\prime \prime}$. The CGSL occupies a total area of 64 ha and receives approximately 500 tons/day of USR from 28 cities of the state, as presented in Figure 1.

These liners are composed by a mixture of two soils: $80 \%$ of clayey sand and $20 \%$ of bentonite clay. The clayey sand is from a quarry located in the CGSL, and the bentonite clay is from a quarry in the city of Boa Vista - PB, apart $25 \mathrm{~km}$ from the CGSL.

Figure 1 - Geographic location of the CGSL and cities involved in the USR destination

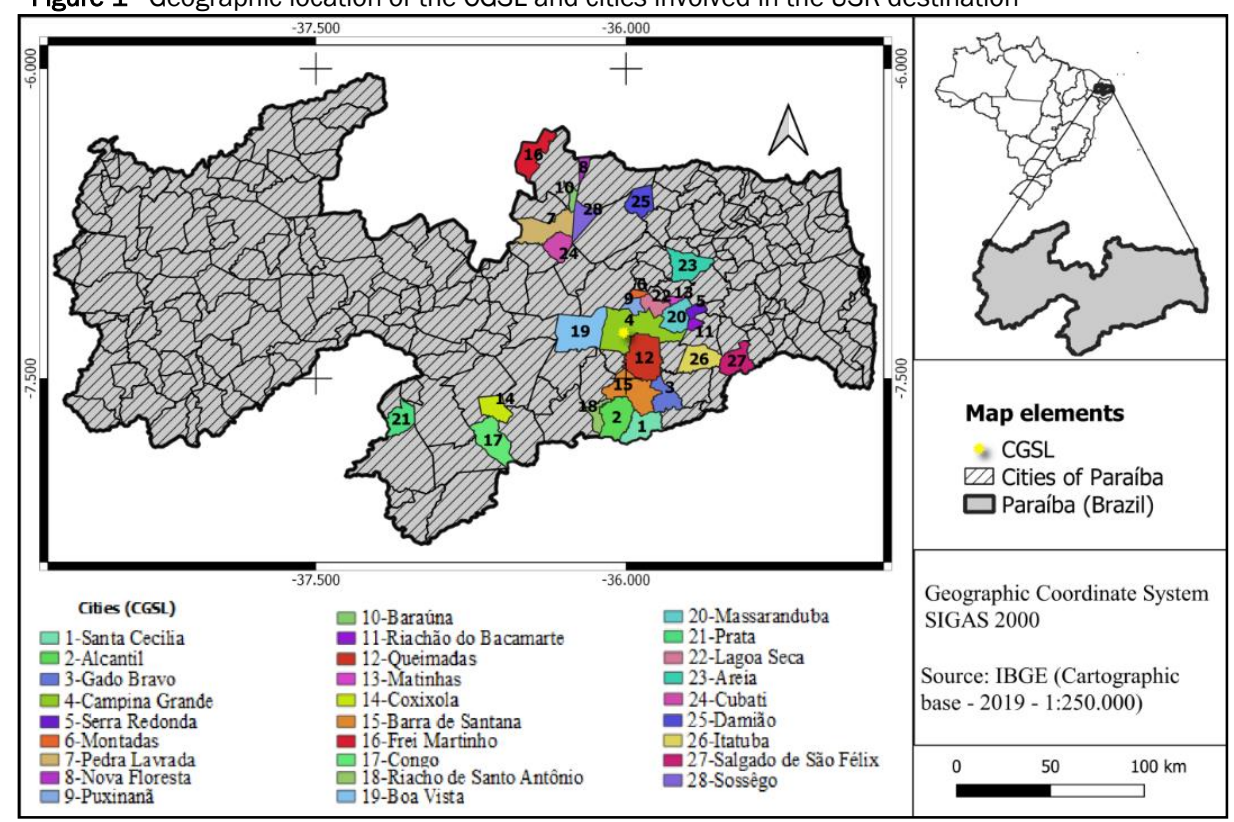


The soil samples were collected at disposal sites around the CGSL, stored in plastic bags, and transported to the Environment Geotechnics Laboratory at Federal University of Campina Grande (UFCG) for the determination of geotechnical and physico-chemical properties, as detailed in Table 1. A mineralogical analysis was also performed using energy dispersive $X$ ray spectroscopy (EDX) and X-ray diffraction (DRX), aiming to determine the oxides and silicates composition, respectively.

The nickel adsorption was individually analyzed for both soils (clayey sand and bentonite clay) and the mixture ( $80 \%$ of cla- yey sand and $20 \%$ of bentonite clay). In addition, it was also compared the adsorption of this metal for an intermediate mixture of $90 \%$ of clayey sand and $10 \%$ of bentonite clay, to verify if the use of bentonite clay in smaller amounts would result in similar adsorptive capacities as those observed in the $20 \%$ mixture employed in CGSL liners. Thus, the focus was to investigate the effects of bentonite clay additions in the nickel adsorption capacity and understand how the physico-chemical properties of each soil and mixtures interfered in the adsorption of the metal.

\begin{tabular}{ll} 
Table 1 - Methods used to determine geotechnical and physico-chemical properties of soils \\
\hline Test & Method \\
\hline Sample preparation & NBR 6457/16 \\
Bulk density & NBR 6458/16 \\
Grain size distribution & NBR 7181/16 \\
Liquid limit & NBR 6459/16 \\
Plastic limit & NBR 7180/16 \\
Permeability to water (variable charge) & NBR $14545 / 00$ \\
Compaction & NBR $7182 / 16$ \\
CEC & \\
Organic matter & \\
pH in $\mathrm{H} 20$ & Embrapa (2017) \\
pH in KCl &
\end{tabular}

\subsection{Batch equilibrium method}

The adsorptive capacity of nickel by soils was determined in laboratory using the batch equilibrium test, following the requirements of test method D4646 (ASTM, 2016). Initially, soil and mixture samples were dried in air, ground, homogenized, and sieved using a $2.0 \mathrm{~mm}$ sieve.

The contaminant solutions were prepared using as reagent nickel II nitrate hexahydrate (Ni(NO3)2.6H2O), diluting it in distilled water in the following initial concentrations of the metal: 45, 90, 180, 360, 720, and 1440 mg.L-1. These values were defined aiming to understand the adsorptive behavior in a wide concentration range. Although this range is considerably higher than the nickel concentrations in leachates and the limits set by environmental test methods, the increase was necessary to guarantee the quantification of palpable values of the metal concentration in the atomic absorption spectroscopy equipment.

In sequence, the $\mathrm{pH}$ of each solution was determined using a mPA210 measurer of MS Tecnopon. In addition, the electrical conductivity was measured for each solution using a Quimis benchtop conductivity meter model Q795A2, confirming the proportionality of conductivity and the amount nickel ions in solutions.

The batch test was performed using soil-solution suspensions in the proportion 1:25 (1g of dry soil for $25 \mathrm{ml}$ of contaminant solution), inserting them in Erlenmeyer flasks (capacity 125 $\mathrm{ml}$ ). The suspensions were agitated in a frequency of $100 \mathrm{rpm}$ in an Orbital shaker, model SL 180 from Solab, during $24 \mathrm{~h}$ (necessary time to reach the equilibrium concentration) and in a controlled temperature of $22 \pm 2{ }^{\circ} \mathrm{C}$ by means of air conditioning system. After agitation, the $\mathrm{pH}$ was registered.

To separate solid and liquid phases, the suspensions were inserted in Falcon tubes with capacity of $50 \mathrm{ml}$ in a Novatecnica centrifuge model NT 815, in a frequency of $3000 \mathrm{rpm}$ (radius of $9.5 \mathrm{~cm}$ ) during $15 \mathrm{~min}$. In sequence, the supernatant was filtered by a Qualy filter, with pore opening of $14 \mu \mathrm{m}$ and thickness of $205 \mu \mathrm{m}$, collected in Falcon tubes and preserved at $5{ }^{\circ} \mathrm{C}$ in an Adamo incubator type BOD. The nickel concentration was quantified using an Agilent flame atomic absorption spectroscopy model AA 240FS.

Isotherms and adsorption parameters

Adsorption isotherms, which are curves obtained from the batch test at a constant temperature, were plotted considering the amount of nickel adsorbed by the soils and mixtures with the respective equilibrium concentrations of suspensions. The amount of adsorbed nickel was determined by the difference between initial and equilibrium concentration values, as in Equation 1.

$$
S=\left(C_{0}-C_{e}\right) \frac{V}{m}
$$

where S (mg.g-1) is the concentration of adsorbed nickel by the soil; CO (mg.L-1) is the initial concentration of the solution; $\mathrm{Ce}$ (mg.L-1) is the equilibrium concentration of the suspension; 
$\mathrm{V}(\mathrm{L})$ is the volume of the contaminant solution of nickel; $\mathrm{m}(\mathrm{g})$ is the mass of dry soil.

The adsorption of nickel by soils and mixtures was analyzed using the Langmuir isotherm, defined by Equation (2). This model estimates the maximum adsorptive capacity of the soil for the metal and can be applied extrapolating the experimental points.

$$
S=\frac{S_{m} K_{L} C_{e}}{\left(1+K_{L} C_{e}\right)}
$$

where $\mathrm{Sm}$ (mg.g-1) is the maximum adsorption capacity and $\mathrm{KL}$ (L.g-1) is the Langmuir constant.

The commonly used Freundlich model, also employed in this work, is described in Equation (3). The use of this model is limited to the concentration range of the experimental data, as the model does not predict a maximum adsorptive capacity, as in the Langmuir model.

$$
S=K_{f} C_{e}^{N}
$$

where Kf (L.g-1) and N (dimensionless) are the coefficient and exponent of Freundlich isotherm, respectively.

The Freundlich model can be simplified by a linear adsorption model. This simplification occurs when the exponent $\mathrm{N}$ is equa to one, as presented in Equation (4). Thus, the angular coefficient of the line is defined as $\mathrm{Kd}$, also known as distribution coefficient, generally represented in terms of L.g-1.

$$
S=K_{d} C_{e}
$$

The use of the linear model is best represented in situations in which there is a proportional increase of the adsorptive capacity of the soil with the equilibrium concentration of solute, as if the saturation of exchange sites available in the soil was never reached. Such situations are particularly observed for low concentrations, as is the case of the concentration of metals in USR (SILVA et al., 2015).

\subsection{Retardation factor}

The nickel mobility was indirectly determined by the retardation factor (R). This factor was obtained using Equation (5), which considers the mobility of metals in saturated soils and relates adsorption to the distribution coefficient. Higher $\mathrm{R}$ values reflect a higher capacity of retardation of the metal flow in the soil.

$$
R=1+\frac{\rho}{n} K_{d}
$$

where $\rho$ (g.dm-3) is the bulk density and $n$ (dimensionless) is the porosity of the soil.

The retardation factor was obtained for specimens previously saturated and compacted in the optimum humidity using standard Proctor energy, simulating sanitary landfill liners.

Although only the $20 \%$ mixture is used in base liners in the CGSL, the retardation factor of nickel was also determined for the $10 \%$ mixture and for the clayey sand, considering the situations in which the proportion of $20 \%$ is not strictly respected in practice. The retardation factor was not calculated for the bentonite clay individually, because this material is not adequate to totally compose liners due to its expansivity potential (GHADR and ASSADI-LANGROUDI, 2018), which can lead to crack formation.

\subsection{Statistical analysis}

The adjustments in the isothermal models were performed using the Gauss-Newton iterative method, applying the least squares methodology using the STATISTICA software version 12.0. A convergence criterion with a value of 10-6 was used, involving a total of 100 iterations. The determination coefficient $\left(R^{2}\right)$ and the Root of the Mean Square Error (RMSE) were adopted as a criterion to analyze the adjustment of the models to the experimental points. The parameter to analyze the quality of the adjusted models was the $p$-value, with a significance level of $5 \%$. The mathematical formulas that define the values of $\mathrm{R}^{2}$ and RMSE are reproduced by Equations (6) and (7), respectively.

$$
\begin{aligned}
& R^{2}=\frac{\sum_{i=1}^{n}\left(\hat{y}_{i}-\bar{y}\right)}{\sum_{i=1}^{n}\left(y_{i}-\bar{y}\right)} \\
& R M S E=\left[\frac{1}{n} \sum_{i=1}^{n}\left(\hat{y}_{i}-\bar{y}_{i}\right)^{2}\right]^{1 / 2}
\end{aligned}
$$

where $\hat{y}_{i}$ is the estimated variable, $y_{i}$ is the observed variable, $\bar{y}$ is the mean of the variables and $\mathrm{n}$ is the number of values of the observed variable.

The $\mathrm{R}^{2}$ varies within 0 and 1 , being your model better fits your data closer it reaches one, while the RMSE indicates better adjustment of the model the smaller the obtained value (MONTGOMERY and RUNGER, 2012).

Using the data analysis tool of the Excel version 2013, it was determined a simple correlation between physico-chemical properties of soils and mixtures with the adsorption parameters of nickel and the retardation factor. The physico-chemical properties were the percentages of sand, silt, and clay, the $\mathrm{CEC}$, organic matter, and $\mathrm{pH}$ in $\mathrm{H} 2 \mathrm{O}$. The expression that defines the correlation coefficient $(r)$ is reproduced by Equation (8).

$$
r=\frac{\sum_{i=1}^{n}\left(x_{i} y_{i}\right)-\frac{1}{n}\left(\sum_{i=1}^{n} x_{i}\right)\left(\sum_{i=1}^{n} y_{i}\right)}{\left[\sum_{i=1}^{n} x_{i}^{2}-\frac{1}{n}\left(\sum_{i=1}^{n} x_{i}\right)^{2}\right]\left[\sum_{i=1}^{n} y_{i}^{2}-\frac{1}{n}\left(\sum_{i=1}^{n} y_{i}\right)^{2}\right]}
$$

where $x_{i}$ and $y_{i}$ are values of the observed variables and $\mathrm{n}$ is the number of values of the observed variables.

\section{RESULTS AND DISCUSSION}

\subsection{Soils Characterization}

The geotechnical properties obtained are detailed in Table 2 It was observed that the $20 \%$ mixture presented a percentage of fines (clay + silt) higher than that of the 10\% mixture; however, the clay fraction was similar in both mixtures, and they were classified as SC (clayey sand) in the Unified Soil Classification System (USCS), as described by standard D2487 (ASTM, 2000). 
The permeability to water for the $20 \%$ mixture, which is the one employed in CGSL base liners, presented a value of 10-8 m.s1. According to test method NBR 13896 (ABNT, 1997), this is an admissible value for waterproofing of sanitary landfill base liners (lower than $5 \times 10-7$ m.s-1). However, CETESB (1993) and USEPA (1993) require values lower than 10-9 m.s-1. For the $10 \%$ mixture and the clayey sand, the values obtained were 10-7 and 10-6 m.s-1, respectively, indicating the waterproofing behavior was improved with addition of bentonite clay.

Table 2 - Geotechnical and physico-chemical properties of soils

\begin{tabular}{|c|c|c|c|c|c|}
\hline \multicolumn{2}{|c|}{ Soil characteristics } & \multirow{2}{*}{$\begin{array}{c}\begin{array}{c}\text { Clayey } \\
\text { sand }\end{array} \\
4\end{array}$} & \multirow{2}{*}{$\begin{array}{c}\begin{array}{c}\text { Bentonite } \\
\text { clay }\end{array} \\
0\end{array}$} & \multirow{2}{*}{$\begin{array}{c}10 \% \text { Mixture } \\
3\end{array}$} & \multirow{2}{*}{$\begin{array}{c}20 \% \text { Mixture } \\
2\end{array}$} \\
\hline \multirow{4}{*}{ Grain size } & Gravel (\%) & & & & \\
\hline & Sand (\%) & 68 & 43 & 58 & 54 \\
\hline & Silt (\%) & 10 & 21 & 12 & 17 \\
\hline & Clay $(\%)$ & 18 & 36 & 27 & 27 \\
\hline \multicolumn{2}{|c|}{ Specific weight of grains (kN.m-3) } & 26.60 & 27.74 & 26.80 & 27.38 \\
\hline \multicolumn{2}{|l|}{ Liquid limit (\%) } & - & 82 & 22 & 24 \\
\hline \multicolumn{2}{|l|}{ Plastic limit (\%) } & - & 38 & 17 & 18 \\
\hline \multicolumn{2}{|l|}{ Plasticity index (\%) } & - & 44 & 5 & 6 \\
\hline \multicolumn{2}{|l|}{ Activity index } & - & 1.52 & 0.18 & 0.22 \\
\hline \multicolumn{2}{|c|}{ USCS classification } & $\mathrm{SC}$ & $\mathrm{CL}$ & $\mathrm{SC}$ & SC \\
\hline \multicolumn{2}{|c|}{ Optimum humidity content (\%) } & 13 & - & 14 & 17 \\
\hline \multicolumn{2}{|c|}{ Maximum dry density (g.cm-3) } & 1.86 & - & 1.82 & 1.76 \\
\hline \multicolumn{2}{|c|}{ Permeability to water (m.s-1) } & $10-6$ & - & $10-7$ & $10-8$ \\
\hline \multirow{6}{*}{$\begin{array}{l}\text { Physico-chemi- } \\
\text { cal characteriza- } \\
\text { tion }\end{array}$} & Total CEC (cmolc.kg-1) & 12.28 & 35.91 & 13.51 & 14.82 \\
\hline & Organic matter (g.kg-1) & 11.00 & 3.99 & 10.82 & 9.03 \\
\hline & Organic carbon (g.kg-1) & 6.38 & 2.31 & 6.28 & 5.24 \\
\hline & $\mathrm{pH}$ H2O (1:2.5) & 5.63 & 9.40 & 7.40 & 8.30 \\
\hline & $\mathrm{pH} \mathrm{KCl} \mathrm{(1:2.5)}$ & 4.71 & 7.68 & 6.27 & 6.63 \\
\hline & Potential of zero charge (PZC) & 3.79 & 5.96 & 5.14 & 4.96 \\
\hline
\end{tabular}

SC: clayed sandy; CL: sandy clay.
In the mineralogical analysis, it was observed the prevalence of silica (SiO2), aluminum (Al2O3), and iron (Fe2O3) in similar percentages for both bentonite clay and clayey sand, as shown in Table 3. The main silicate minerals identified in the soils are also indicated in Table 3, with emphasis on the predominance of quartz and feldspar in both soils and the presence of montmorillonite and kaolinite in bentonite clay and sand clay, respectively. The presence of montmorillonite can explain the better waterproofing behavior of the bentonite clay, because this clay mineral can expand when accumulates water in its internal layers, decreasing fluids percolation (MASSAD, 2016).

Table 3 - Mineralogical characterization of bentonite clay ad clayey sand

\begin{tabular}{|c|c|c|c|c|c|c|c|}
\hline \multirow{2}{*}{ Soil } & \multicolumn{3}{|c|}{ Main oxide minerals (\%) } & \multirow[b]{2}{*}{ K2O } & \multirow[b]{2}{*}{$\mathrm{CaO}$} & \multirow{2}{*}{ Main silicate minerals (\%) } & \\
\hline & $\mathrm{SiO} 2$ & $\mathrm{Al} 203$ & $\mathrm{Fe} 203$ & & & & \\
\hline Clayey sand & 61,2 & 19,6 & 8,0 & 4,3 & 2,4 & $\begin{array}{l}\text { quartz } \\
\text { feldspar } \\
\text { kaolinite }\end{array}$ & $\begin{array}{l}69,3 \\
18,5 \\
7,1\end{array}$ \\
\hline $\begin{array}{l}\text { Bentonite } \\
\text { clay }\end{array}$ & 62,3 & 21,2 & 6,7 & 1,9 & 2,4 & $\begin{array}{l}\text { quartz } \\
\text { feldspar } \\
\text { montmorillonite }\end{array}$ & $\begin{array}{l}61,1 \\
13,6 \\
8,9\end{array}$ \\
\hline
\end{tabular}

Table 2 also presents the physico-chemical properties of soils. The organic matter content was higher for the clayey sand compared to the bentonite clay, while in the mixtures, the contents were similar to the one of clayey sand. In contrast, the
CEC values were higher for the bentonite clay compared to the clayey sand, indicating a higher tendency of cation exchange with the addition of clay in the mixtures. This occurs due to the high negative electrical charge and higher specific surface of 
clay minerals that compose the bentonite clay (BOSCOV, 2008).

The $\mathrm{pH}$ values obtained for soils and mixtures were higher than the respective values of potential of zero charge (PZC) which represents the equality condition of opposed superficial charges. Soils with this characteristic have a predominance of negative superficial charge $(\mathrm{OH}-)$, favoring the adsorption of cations (APEEL et al., 2003).

Due to the alkaline $\mathrm{pH}$ of the bentonite clay and the $\mathrm{pH}$ of the clayey sand under 6.0, as presented in Table 2, the equilibrium concentrations obtained in the batch test exhibited $\mathrm{pH}$ in the range of 4.4 to 5.0 for the clayey sand and 6.4 to 6.8 for bentonite clay and mixtures. Levels of acid $\mathrm{pH}$ in soil indicate high concentration of $\mathrm{H}+$ protons, hindering adsorption reactions of metal in soil (PINCOVSCHI et al., 2017). Thus, the addition of bentonite clay to the clayey sand can decrease the mobility of nickel ions due to the increase of negative charges, consequently mitigating surface and groundwaters contamination.

\subsection{Adsorption isotherms}

The Freundlich and Langmuir isotherms were adjusted to the experimental points of the batch test with nickel and plotted in Figure 2. These adjustments allowed the estimation of adsorption parameters related to each model, as presented in Table 4.

Figure 2 - Adsorption isotherms of nickel, representing the concentration of the adsorbed metal in the soil (S) as a function of equilibrium concentration in the solution (Ce), for: (a) clayey sand soil, (b) bentonite clay soil, (c) mixture with $10 \%$ and (d) $20 \%$ of bentonite clay soil.

(a)

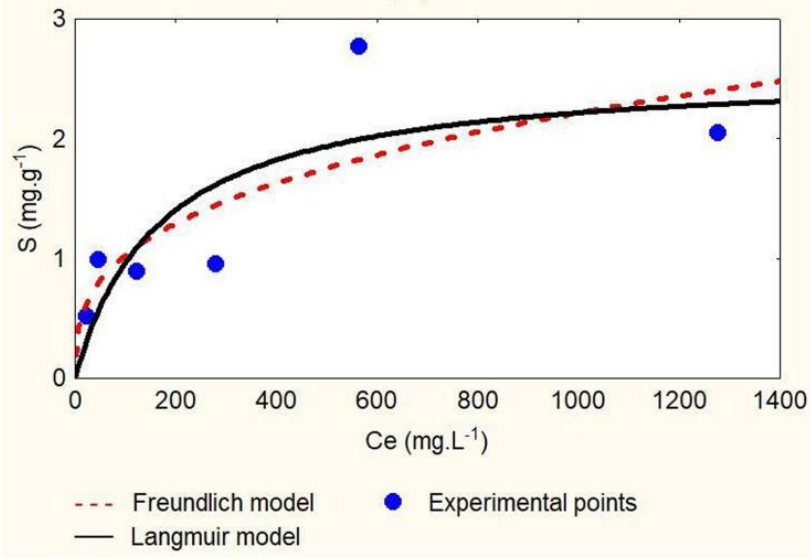

(c)

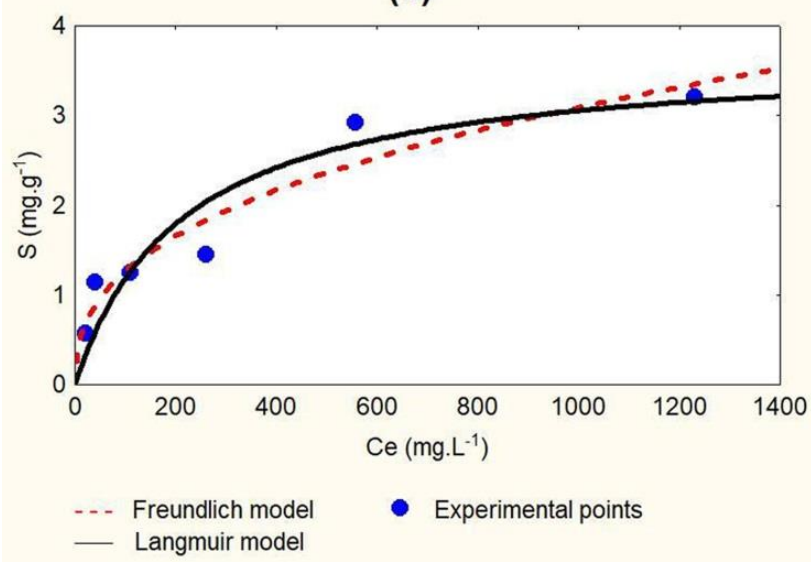

The maximum adsorption capacity of nickel estimated in the Langmuir model was estimated the highest value for the bentonite clay (7.885 mg.g-1) and the lowest for the clayey sand (2.611 mg.g-1). For the mixtures, the maximum adsorption capacity decreased with the reduction in the bentonite clay content. High adsorption capacities suggest lower probability of leaching of metal towards soils and surface and groundwaters (SOBTI and SINGH 2019). Abdelwaheb et al. (2019) studied (b)

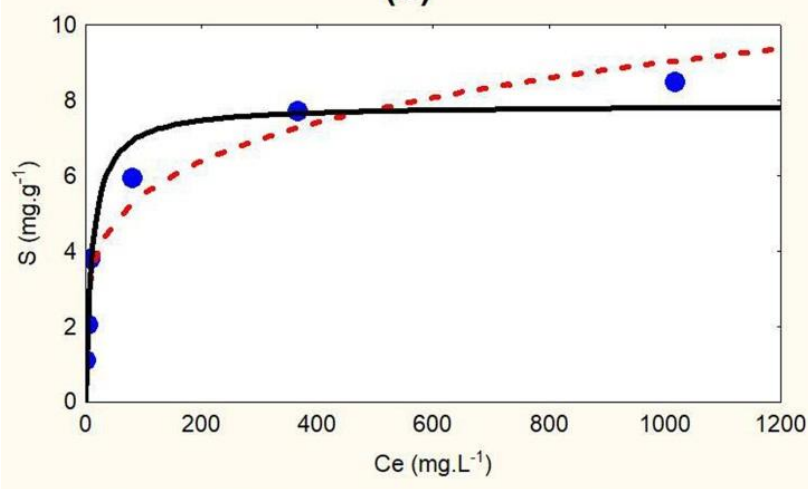

-. Freundlich model - Langmuir model

(d)

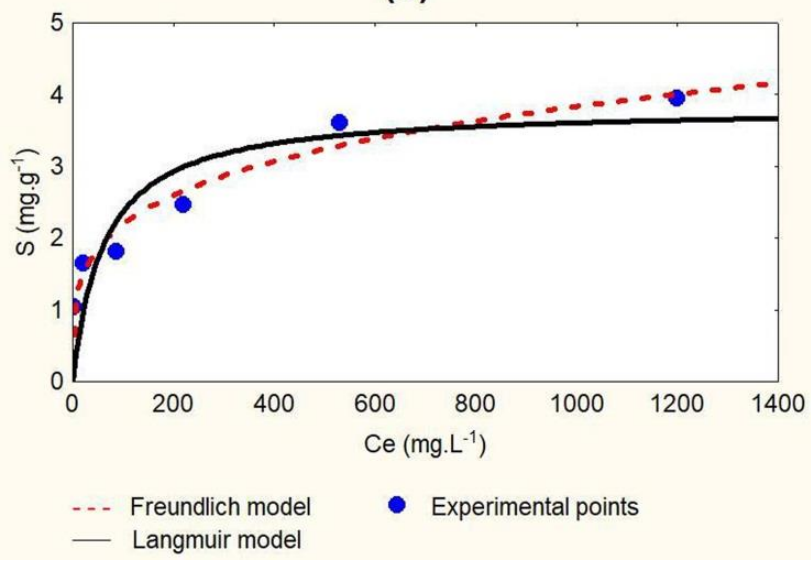

nickel adsorption in mixtures of sandy and clayey soils with CEC of 3.5 and 25 meq/100g, respectively, and obtained maximum adsorption capacity $(\mathrm{Sm})$ values in the range of 0.19 to $0.58 \mathrm{mg} . \mathrm{g}-1$ for a temperature of $19 \pm 1^{\circ} \mathrm{C}$ and $\mathrm{pH}$ range of 7 to 7.8. Despite the alkaline $\mathrm{pH}$, the $\mathrm{CEC}$ of soils may have contributed to the low Sm values, when compared to the results obtained to the CGSL soils (CEC > 12 cmolc.kg-1). 
Table 4 - Adsorption parameters of nickel and adjustment criteria to the isotherm models

\begin{tabular}{|c|c|c|c|c|c|c|}
\hline Soil & Model & Parameter & $\begin{array}{c}\text { Estimated } \\
\text { value }\end{array}$ & $\mathrm{R}^{2}$ & RMSE & p-value \\
\hline \multirow{3}{*}{ Clayey Sand } & \multirow{2}{*}{ Freundlich } & Kf1 & 0.219 & \multirow{2}{*}{0.636} & \multirow{2}{*}{0.193} & \multirow{2}{*}{$8,2 \cdot 10-3$} \\
\hline & & $\mathrm{N}$ & 0.335 & & & \\
\hline & Langmuir & $\begin{array}{l}\text { KL2 } \\
\text { Sm3 }\end{array}$ & $\begin{array}{l}0.006 \\
2.611\end{array}$ & \multirow[t]{2}{*}{0.631} & \multirow[t]{2}{*}{0.194} & $8,4 \cdot 10-3$ \\
\hline \multirow{4}{*}{ Bentonite clay } & \multirow{2}{*}{ Freundlich } & $\mathrm{Kf}$ & 2.058 & & & \multirow[b]{2}{*}{$1,6.10-4$} \\
\hline & & $\mathrm{N}$ & 0.214 & 0.948 & 0.256 & \\
\hline & \multirow[b]{2}{*}{ Langmuir } & $\mathrm{KL}$ & 0.090 & \multirow[b]{2}{*}{0.944} & \multirow[b]{2}{*}{0.265} & \multirow[b]{2}{*}{$1,9.10-4$} \\
\hline & & $\mathrm{Sm}$ & 7.885 & & & \\
\hline \multirow{4}{*}{$\begin{array}{l}\text { Mixture with } 10 \% \text { of } \\
\text { bentonite clay }\end{array}$} & \multirow{2}{*}{ Freundlich } & $\mathrm{Kf}$ & 0.213 & \multirow{2}{*}{0.918} & \multirow{2}{*}{0.112} & \multirow{2}{*}{$3,6.10-4$} \\
\hline & & $\mathrm{N}$ & 0.387 & & & \\
\hline & \multirow{2}{*}{ Langmuir } & $\mathrm{KL}$ & 0.005 & \multirow{2}{*}{0.864} & \multirow{2}{*}{0.145} & \multirow{2}{*}{$1,0.10-3$} \\
\hline & & $\mathrm{Sm}$ & 3.706 & & & \\
\hline \multirow{4}{*}{$\begin{array}{l}\text { Mixture with } 20 \% \text { of } \\
\text { bentonite clay }\end{array}$} & \multirow{2}{*}{ Freundlich } & $\mathrm{Kf}$ & 0.722 & \multirow{2}{*}{0.956} & \multirow{2}{*}{0.089} & \multirow{2}{*}{$4,8 \cdot 10-5$} \\
\hline & & $\mathrm{N}$ & 0.242 & & & \\
\hline & \multirow{2}{*}{ Langmuir } & $\mathrm{KL}$ & 0.016 & \multirow{2}{*}{0.717} & \multirow{2}{*}{0.228} & \multirow{2}{*}{$2,0.10-3$} \\
\hline & & $\mathrm{Sm}$ & 3.831 & & & \\
\hline
\end{tabular}

1 (L.g-1); 2 (L.g-1); 3 (mg.g-1)

One of the parameters obtained by the Freundlich isotherm was the exponent $\mathrm{N}$ which reflects the degree of heterogeneity of the adsorbent surface. When this parameter is equal to one, it is established a linear relationship for the adsorption (ZUQUETTE et al., 2008). Elbana et al. (2018) obtained N values in the range of 0.54 to 0.90 for the adsorption of nickel in ten types of soils, using maximum initial concentrations of 150 mg.L-1. In this adsorption study with CGSL soils, the $\mathrm{N}$ was in the range of 0.21 to 0.39 likely due to using of high concentrations up to 1440 mg.L-1. Among other characteristics of soil and contaminant solution, high concentrations of metallic ions in solution tend to decrease the availability of adsorption sites in the surface of the adsorbent, distancing it from a linear behavior (SOUSA NETO et al., 2012).

The adjustment criteria, $\mathrm{R}^{2}$ and RMSE, indicate that the Freundlich model presented a better fit for soils and mixtures, when compared to the Langmuir model. As the value of all adjusted models was lower than the level of significance, it can be said that the quality of these adjusted models was significant (Table 4). It was observed that the Langmuir model was more representative for bentonite clay, possibly due to the characteristic of this soil as the best adsorbent. The Freundlich model is based on the adsorption of metals on heterogeneous surfaces, which is typical in soils, while the Langmuir model is based on adsorption on a homogeneous monolayer surface (JIANG et al., 2010).

Ma, X et al. (2019) had also achieved a better adjustment to the Freundlich model for the adsorption of nickel in soils. In addition, an increase in nickel adsorption was observed due to the presence of organic matter and the rise of temperature, obtaining adsorption rates of 99.57 and $99.84 \%$ for sediments of lake and soils, respectively.

\subsection{Retardation factor}

Table 4 presents values of distribution coefficient (Kd), bulk density, porosity, and retardation factor $(\mathrm{R})$ obtained in compacted specimens for each mixture and for the clayey sand. For higher contents of bentonite clays, it was observed an increase in Kd values, which means an increase of the angular coefficient of the linear isotherm, indicating higher adsorption capacities. The additions of clay have also provoked lower bulk densities of specimens and higher porosity values which can be explained by the increase in the percentage of fines in mixtures, enabling the water to be strongly adsorbed by the clay minerals of the soil.

The $\mathrm{R}$ value increased with the addition of bentonite clay as consequence of the higher $\mathrm{CEC}, \mathrm{pH}$, and fine fraction (clay + silt) values of mixtures with 10 and $20 \%$, compared to the clayey sand. In fact, these characteristics are directly related to a higher retention of metals by the colloids of the soil, as observed by several authors (COSTA et al., 2017; OLIVEIRA et al., 2018).

Considering the CGSL liners, the mixture with $20 \%$ of bentonite clay represented an increase of $24.6 \%$ and $3.4 \%$ of the $R$ value when compared to the clayey sand individually and the $10 \%$ mixture, respectively. Thus, although the $\mathrm{R}$ is only an indirect estimative of the mobility of metals in the soil, the results obtained indicate a better adsorption of nickel for the $20 \%$ mixture, followed by the $10 \%$ mixture and the clayey sand. 
Table 4 - Retardation factor (R) for the clayey sand and mixtures, with distribution coefficient (Kd), bulk density ( $\rho)$, and porosity ( $n$ ) values

\begin{tabular}{lllll}
\hline Soil / mixture & Kd (L.g-1) & $\rho(g . d m-3)$ & $\mathrm{n}$ & $\mathrm{R}$ \\
\hline Clayey sand & 0.002258 & 1.82 & 0.31 & 14.04 \\
$10 \%$ Mixture & 0.003226 & 1.73 & 0.35 & 16.92 \\
$20 \%$ Mixture & 0.003605 & 1.68 & 0.37 & 17.50 \\
\hline
\end{tabular}

\subsection{Correlations between soil properties and adsorption pa- rameters}

Table 5 presents correlation coefficients obtained from physico-chemical properties of soils with the Freundlich and Langmuir adsorption parameters and the R factor. Among the analyzed properties, the CEC was the one that presented a better correlation, indicating its significative influence in the adsorption of metals in soils. The increase of CEC provoked higher values of $\mathrm{Kf}, \mathrm{KL}, \mathrm{Sm}$, and $\mathrm{R}$, indicating a higher nickel adsorption capacity and, as a consequence, a lower availability of this metal to be transported towards surface and groundwater resources. The $\mathrm{N}$ parameter was the only one that exhibited a negative correlation with the CEC, which suggests a possible saturation of available exchange sites in the surface of soils (MUSTAFA et al., 2004).

The percentages of silt and clay had a positive influence on the nickel adsorption. This occurs due to the considerable presence of clay minerals, whose negative electrical charges attract metallic cations of the soil solution. The $\mathrm{pH}$ had also a positive influence on the nickel adsorption, as higher $\mathrm{pH}$ va- lues provided high $\mathrm{OH}$ - concentrations and, as a consequence, favored the formation of covalent bonds with nickel ions in solution (PINCOVSCHI et al., 2017). The pH influence was observed in the adsorption of other heavy metals, such as lead (OLIVEIRA et al., 2018).

The sand fraction had unfavorable influence on metal adsorption, as it has greater particle diameters and, consequently, smaller contact area of grains with the nickel solution compared to silt and clay fractions. For organic matter, although it favors the adsorption of metal cations, the results did not indicate a positive correlation with the parameters $\mathrm{Kf}, \mathrm{KL}$, Smax and $\mathrm{R}$. This was probably due to the lower content of organic matter quantified in bentonite clay. In addition, the correlations are not able to indicate the particular influence of each property of the soil, but in a joint way, suggesting a trend of behavior between the values of a given property of the soil with the adsorption parameters of the soil metal. Other studies, in turn, pointed to good positive correlations between organic matter and metal adsorption parameters (SILVEIRA et al., 2002; ALLEONI et al., 2005).

Table 5 - Correlation coefficients of physico-chemical properties of soils and nickel adsorption and retardation factor parameters

\begin{tabular}{lccccc} 
Soil properties & Kf & N & KL & Sm & R \\
\hline \% Sand & -0.90 & 0.73 & -0.86 & -0.93 & -0.99 \\
\% Silt & 0.93 & -0.89 & 0.87 & 0.89 & 0.88 \\
\% Clay & 0.86 & -0.61 & 0.84 & 0.93 & 0.96 \\
CEC & 0.98 & -0.71 & 0.99 & 0.99 & 0.97 \\
Organic matter & -0.99 & 0.82 & -0.99 & -0.98 & -0.78 \\
pH in H20 & 0.83 & -0.73 & 0.77 & 0.86 & 0.99 \\
\hline
\end{tabular}

\section{CONCLUSIONS}

The isotherms of nickel adsorption for soils and mixtures were better adjusted to the Freundlich model, considering $\mathrm{R}^{2}$ and RMSE criteria.

Additions of bentonite clay to the clayey sand improved the adsorptive capacity of nickel and decreased the mobility of this metal, particularly the mixture with $20 \%$ of bentonite clay, indicating this composition can be used as liners in sanitary landfills aiming to reduce the migration of nickel towards soils and surface and groundwaters.

The CEC was the most influencing physico-chemical property in the adsorption of nickel in soils and mixtures, contributing to a better retention of the metal and its lower availability in transport flows.

The study of metal adsorption in soils used as liners in sanitary landfills should be encouraged and extended to bioremediation of soils in areas contaminated by heavy metals.

\section{REFERENCES}

ABDELWAHEB, M.; JEBALI, K.; DHAOUADI, H.; DRIDI-DHAOUADI, S. Adsorption of nitrate, phosphate, nickel and lead on soils: Risk of groundwater contamination. Ecotoxicology and environmental safety, v. 179, p. 182-187, 2019. https://doi.org/10.1016/j.ecoenv.2019.04.040 
ABNT - Associação Brasileira de Normas Técnicas. NBR 13896: Aterros de resíduos não perigosos - Critérios para projeto, implantação e operação. Rio de Janeiro: ABNT, 1997. 12p.

ABNT - Associação Brasileira de Normas Técnicas. NBR 14545: Solo: determinação do coeficiente de permeabilidade de solos argilosos a carga variável. Rio de Janeiro: ABNT, 2000. 12 p.

ABNT - Associação Brasileira de Normas Técnicas. NBR 6457: Amostra de solo: preparação para ensaios de compactação e ensaios de caracterização. Rio de Janeiro: ABNT, 2016. 8 p.

ABNT - Associação Brasileira de Normas Técnicas. NBR 6458 Grãos de pedregulho retidos na peneira de abertura $4,8 \mathrm{~mm}$ Determinação da massa específica, da massa específica aparente e da absorção de água. Rio de Janeiro: ABNT, 2016. 10 p.

ABNT - Associação Brasileira de Normas Técnicas. NBR 6459: Determinação do limite de liquidez. Rio de Janeiro: ABNT, 2016. 5 p.

ABNT - Associação Brasileira de Normas Técnicas.NBR 7180: Determinação do limite de plasticidade. Rio de Janeiro: ABNT, 2016. 3 p.

ABNT - Associação Brasileira de Normas Técnicas. NBR 7181: Análise granulométrica. Rio de Janeiro: ABNT, 2016. 12 p.

ABNT - Associação Brasileira de Normas Técnicas. NBR 7182: Compactação - Procedimento. Rio de Janeiro: ABNT, 2016. 9 p.

ALBERTI, E. A.; BUENO, B. M. P.; D'OLIVEIRA, A. S. C. M. Processamento de ligas de níquel com técnica de manufatura aditiva utilizando plasma por arco transferido. Soldagem \& Inspeção, v. 20, n. 2, p. 137-147, 2015. https://doi.org/10.1590/0104-9224/SI2002.02

ALLEONI, L. R. F.; IGLESIAS, C. S. M.; MELLO, S. C.; CAMARGO, O. A.; CASAGRANDE, J. C.; LAVORENTI, N. A. Atributos do solo relacionados à adsorção de cádmio e cobre em solos tropicais. Acta Scientiarum. Agronomy, v. 27, n. 4, p. 729-737, 2005. https://doi.org/10.4025/actasciagron.v27i4.1348

ASTM - AMERICAN SOCIETY FOR TESTING AND MATERIALS. ASTM D2487-00: Standard Practice for Classification of Soils for Engineering Purposes (Unified Soil Classification System). 2000 .

ASTM - AMERICAN SOCIETY FOR TESTING AND MATERIALS. ASTM D4646-16: Standard test method for 24-h batch-type measurement of contaminant sorption by soils and sediments. 2016.

APEEL, C.; MA, L. Q.; RHUEL, R. D. Point of zero charge determination in soils and minerals via traditional methods and detection of electroacoustic mobility. Geoderma, v. 113, p. 7793, 2003. https://doi.org/10.1016/S0016-7061(02)00316$\underline{6}$

BOSCOV, M. E. G. Geotecnia ambiental. São Paulo: Oficina de Textos, 2008.

BUDIHARDJO, M. A. Predicting Leachate Containing Nickel and Chromium Migration Through Single-and Double-liner System Landfill. The Journal of Solid Waste Technology and Management, v. 44, n. 3, p. 206-213, 2018 https://doi.org/10.5276/JSWTM.2018.206

BURAGOHAIN, P.; GARG, A.; LIN, P.; HONG, M., Yi, Z.; SREEDEEP, S. Exploring Potential of Fly Ash-Bentonite Mix as a Liner Material in Waste Containment Systems Under Concept of
Sponge City. Advances in Civil Engineering Materials, v. 7, n.1, p. 46-70, 2018. https://doi.org/10.1520/ACEM20170092

CONAMA. Resolução n 357, de 17 de março de 2005 - Dispõe sobre a classificação dos corpos de água e diretrizes ambientais para o seu enquadramento, bem como estabelece as condições e padrões de lançamento de efluentes, e dá outras providências; publicada no Diário Oficial da União em 18/03/2005; Brasília, DF.

CONAMA, Resolução $n^{\circ}$ 396, de 3 de abril de 2008 - Dispõe sobre a classificação e diretrizes ambientais para o enquadramento das águas subterrâneas e dá outras providências; publicada no Diário Oficial da União em 07/04/2008; Brasília, DF.

CONAMA, Resolução $n^{\circ}$ 420, de 28 de dezembro de 2009 . Dispõe sobre critérios e valores orientadores de qualidade do solo quanto à presença de substâncias químicas e estabelece diretrizes para o gerenciamento ambiental de áreas contaminadas por essas substâncias em decorrência de atividades antrópicas"; publicada no Diário Oficial da União em 30/012/2009; Brasília, DF.

COSTA, J. J. G.; REIGOSA, M. J.; MATÍAS, J. M.; COVELO, E. F. Soil $\mathrm{Cd}, \mathrm{Cr}, \mathrm{Cu}, \mathrm{Ni}, \mathrm{Pb}$ and $\mathrm{Zn}$ sorption and retention models using SVM: variable selection and competitive model. Science of the Total Environment, v. 593, p. 508-522, 2017. https://doi.org/10.1016/i.scitotenv.2017.03.195

CETESB - Companhia Ambiental do Estado de São Paulo. Resíduos Sólidos Industriais. 2. ed. São Paulo: CETESB. 233p, 1993.

ELBANA, T. A.; SELIM, H. M.; AKRAMI, N.; NEWMAN, A.; SHAHEEN, S. M.; RINKLEBE, J. Freundlich sorption parameters for cadmium, copper, nickel, lead, and zinc for different soils: Influence of kinetics. Geoderma, 324, 80-88, 2018. https://doi.org/10.1016/i.geoderma.2018.03.019

FETTER, C. W.; BOVING, T.; KREAMER, D. Contaminant hydrogeology. Waveland Press: Long Grove, 3 ed., 2018.

GHADR, S.; ASSADI-LANGROUDI, A. Structure-based hydro-mechanical properties of sand-bentonite composites. Engineering Geology, v. 235, p. 53-63, 2018. https://doi.org/10.1016/i.enggeo.2018.02.002

HAQUE, M. A. Effects of specimen size and mix ratio on the nickel migration behavior of landfill waste mixed mortar. Journal of environmental management, v. 190, p. 290-301, 2017. https://doi.org/10.1016/i.jenvman.2016.12.061

JIANG, M.; JIN, X.; LU, X.; CHEN, Z. Adsorption of Pb (II), Cd (II), $\mathrm{Ni}$ (II) and $\mathrm{Cu}$ (II) onto natural kaolinite clay. Desalination, v. 252, p. 33-39, 2010. https://doi.org/10.1016/i.desal.2009.11.005

LOCASTRO, J. K.; De ANGELIS, B. L. D. Barreira de impermeabilização: configurações aplicadas em aterros sanitários. Revista Eletrônica em Gestão, Educação e Tecnologia Ambiental, $\begin{array}{llll}\text { v. } 20,200-210, & \text { p. }\end{array}$ https://doi.org/10.5902/2236117019963

MARTINELLI, A. C.; BARRADA, R. V.; FERREIRA, S. A. D.; FREITAS, M. B. J. G.; LELIS, M. F. F. Avaliação da lixiviação do cádmio e níquel provenientes da degradação de baterias níquelcádmio em uma coluna de solo. Química Nova, v. 37, n. 3, p. 465-472, 2014.

MASSAD, F. Mecânica dos solos experimental. São Paulo: Oficina de Textos, 2016.

MA, X.; SUN, J.; REN, L.; GUO, M.; WANG, Y.; Han, X. Study on the nickel adsorption characteristics of lake sediments and 
soil. Applied ecology and environmental research, v. 17, n. 6, p. 13239-13251, 2019. https://doi.org/10.15666/aeer/1706 1323913251

MOHAMMED, S. A. S.; SANAULLA, P. F.; MOGHAL, A. A. B. SUstainable Use of Locally Available Red Earth and Black Cotton Soils in Retaining $\mathrm{Cd} 2+$ and $\mathrm{Ni} 2+$ from Aqueous Solutions. International Journal of Civil Engineering, v. 14, n. 7, p. 491-505, 2016. https://doi.org/10.1007/s40999-016-0052-z

MONTGOMERY, D. C.; RUNGER, G. C. estatística aplicada e probabilidade para engenheiros. Rio de Janeiro: LTC, 2012.

MUSTAFA, G.; SINGH, B.; KOOKANA, R. S. Cadmium adsorption and desorption behaviour on goethite at low equilibrium concentrations: effects of $\mathrm{pH}$ and index cations. Chemosphere, $\mathrm{v}$. 57, n. 10, p. 1325-1333, 2004. https://doi.org/10.1016/j.chemosphere.2004.08.087

SOUSA NETO, V. O.; CARVALHO, T. V.; HONORATO S. B.; GOMES, C. L.; BARROS, F. C. F.; SILVA, M. A. A.; FREIRE, P. T. C.; NASCIMENTO, R. F. Coconut bagasse treated by thiourea/amonium solution for cadmium removal: Kinetic and adsorption equilibrium. BioResources, v. 7, n. 2, p. 1504-1524, 2012. https://doi.org/10.15376/biores.7.2.1504-1524

NICKEL INSTITUTE. Nickel \& Nickel Compounds Carcinogenicity. Nipera, v. 2, p. 1-8, dez. 2018.

OLIVEIRA, S. A.; TAVARES, S. R. L.; BARBOSA, M. C. Pb Adsorption on Soil Typical to an Ammunition Destruction Site. Bulletin of environmental contamination and toxicology, v. 101, n. 3, p. 365-371, 2018. https://doi.org/10.1007/s00128-0182403-8

PINCOVSCHI, I.; NEACSU, N.; MODROGAN, C. The Adsorbtion of Lead, Copper, Chrome and Nickel lons from Waste Waters in Agricultural Argilaceous Soils. Revista de Chimie, v. 68, n. 4, p. 635-638, 2017. https://doi.org/10.37358/RC.17.4.5520

SELIM, H. Transport \& Fate of Chemicals in Soils: Principles \& Applications. Boca Raton: CRC Press, 2014. https://doi.org/10.1201/b17405

SILVA, A. S.; RIBEIRO, L. S.; PAIVA, W.; MELO, M. C.; MONTEIRO, V. E. D. Avaliação do potencial tóxico dos resíduos sólidos urbanos da cidade de Campina Grande-PB. Matéria (Rio de Janeiro), v. 20, n. 4, p. 840-851, 2015. https://doi.org/10.1590/S1517-707620150004.0091

SILVEIRA, M. L. A.; ALLEONI, L. R. F.; CAMARGO, O. A.; CASAGRANDE, J. S. Copper adsorption in oxidic soils after removal of organic matter and iron oxides. Communications in Soil Science and Plant Analysis, v. 33, n. 19-20, p. 3581-3592, 2002. https://doi.org/10.1081/CSS-120015907

SOBTI, J.; SINGH, S. K. Sorption behaviour of heavy metals in sand-bentonite-coal ash mixes for use as a liner material in landfills. International Journal of Geotechnical Engineering, v. 13, n. 5, p. 411-424, 2019. https://doi.org/10.1080/19386362.2017.1363346

SPARKS, D. L. Environmental Soil Chemistry. 2.ed. San Diego: America Press, 2003. https://doi.org/10.1016/B978012656446-4/50001-3

TEIXEIRA, P. C.; DONAGEMMA, G. K.; FONTANA, A.; TEIXEIRA, W. G. (Ed.). Manual de métodos de análise de solo. 3. ed. Brasília, DF: Embrapa, 2017.

TRIPATHI, N.; CHOPPALA, G.; SINGH, R. S.; SRIVASTAVA, P.; SESHADRI, B. Sorption kinetics of zinc and nickel on modified chitosan. Environmental monitoring and assessment, v. 188, n. 9, p. 1-13, 2016. https://doi.org/10.1007/s10661-016$\underline{5499-5}$

USEPA - United States Environmental Protection Agency. So lid waste disposal facility criteria technical manual. Office of solid waste and emergency response. EPA-530-R-93-017. Washington DC.: USEPA, 1993. p.11.

ZHU, H.; XIAO, X.; GUO, Z.; HAN, X.; LIANG, Y.; ZHANG, Y.; $Z \mathrm{HOU}, \mathrm{C}$. Adsorption of vanadium (V) on natural kaolinite and montmorillonite: characteristics and mechanism. Applied Clay Science, v. 161, p. 310-316, 2018. https://doi.org/10.1016/j.clay.2018.04.035

ZUQUETTE, L. V.; SILVA Jr, E. M.; GARCIA, A. Aspectos de sorção para os materiais inconsolidados da região de São Carlos (SP), Brasil. Rem: Revista Escola de Minas, v. 61, n. 2, p. 219-230, 2008.https://doi.org/10.1590/S037044672008000200017 